RESEARCH ARTICLE

\title{
Impact of overall equipment effectiveness on return on investment in the Nigerian cement manufacturing industry
}

\author{
Ebomah Ernest Monday ${ }^{1^{*}}$ Ugbomhe O. Ugbomhe $^{2}$ \\ ${ }^{1}$ Department of Business Administration, Faculty of Management Sciences, National Open University of Nigeria, Nigeria \\ ${ }^{2}$ Department of Business Administration, Faculty of Management Sciences, Ambrose Alli University, Nigeria
}

\section{Check for updates}

Correspondence to: Ebomah Ernest Monday, Department of Business Administration, Faculty of Management Sciences, National Open University of Nigeria, Nigeria; E-mail: ernestem1234@gmail.com

Received: April 1, 2021;

Accepted: April 25, 2021;

Published: April 27, 2021

Citation: Monday EE and Ugbomhe UO. Impact of overall equipment effectiveness on return on investment in the Nigerian cement manufacturing industry. Front Manage Bus, 2021, 2(1): 87-94. https://doi.org/10.25082/FMB.2021.01.003

Copyright: () 2021 Ebomah Ernest Monday and Ugbomhe $\mathrm{O}$. Ugbomhe. This is an open access article distributed under the terms of the Creative Commons Attribution License, which permits unrestricted use, distribution, and reproduction in any medium, provided the original author and source are credited.

\begin{abstract}
The formidable challenge of maintenance of heavy duty equipment for the dayto-day manufacturing activities informed this research investigation. The study examined the impact of overall equipment effectiveness on return on investment in the Nigerian cement manufacturing industry. It focused on the key indicators of overall equipment effectiveness and their impact on return on investment. Ex-post facto research design was adopted in conducting the empirical investigation. The firms in the industry quoted in the Nigeria Stock Exchange (NSE) were studied. Longitudinal data of 15 years observation (2005-2019) were obtained and analyzed with ordinary least squares regression (system-OLS). The key indicators of overall equipment effectiveness subjected to empirical test proved positively significant to return on investment at the Coefficient values $\mathrm{a}_{1}, \mathrm{a}_{2} \& \mathrm{a}_{3}>0$; Prob.-values $\mathrm{a}_{1}, \mathrm{a}_{2}, \& \mathrm{a}_{3}<0.05$ and $\mathrm{t}$-Statistic values $\mathrm{a}_{1}, \mathrm{a}_{2}, \& \mathrm{a}_{3}$ absolutely $\geq 2$. These analysis results suggested that machine availability rate (MAR), machine production rate (MPR), product quality rate (PQR) variables of overall equipment effectiveness have significant linear effect on ROI. Based on these results, the study therefore recommends among others for top management's support and commitment to proactive and continuous improvement production facilities maintenance for improved overall equipment effectiveness and sustainable corporate performance of firms in the industry.
\end{abstract}

Keywords: Overall Equipment Effectiveness (OEE), Machine Availability Rate (MAR), Machine Performance Rate (MPR), Product Quality Rate (PQR), corporate performance, Return on Investment (ROI)

\section{Introduction}

The increased global competition in today's manufacturing industry necessitates the need for manufacturing firms to effectively and efficiently maintenance their production facilities to gain competitive advantage. Also, the advent of manufacturing philosophies and the increased use of automation in today's manufacturing have led to network of maintenance services for overall equipment effectiveness [1].

Effective performance of a production system lies not only on the operational design of the system; it requires maintenance function either to keeps the system in an operational condition or to restore the system back to functional stage after breakdown has occurred [2]. Maintenance function is an organization-wide strategy that adds to effectiveness of production environment, customers' value and organizational performance [3].

One of the major challenges in today's manufacturing is the state of production facilities. The effectiveness of manufacturing firms is sub-optimized at the instance of poor maintenance. The concept of overall equipment effectiveness evolved from production facilities maintenance and it rests on the premise that no facility can operate at peak efficiency without being maintained. Thus, the philosophy behind overall equipment effectiveness is for the manufacturing firms to move into World Class Performance (WCP) where advanced manufacturing strategies such as just-in-time, agile manufacturing, lean manufacturing; flexible manufacturing and continuous improvement can be effectively adopted to meet the market demand of products and services for organizational corporate performance [4].

The corporate performance of manufacturing firms is premised on overall equipment effectiveness and is measured on the basis of non-financial and financial performance. Ricardo 
\& Wade (2001) [5] see performance of a firm as the ability to attain goals by using human, material, machine and technological resources in an effective and efficient manner.

Poor maintenance affects overall equipment effectiveness of manufacturing firms. In the Sub-Saharan African countries, evidence of overall equipment ineffectiveness abounds in the use of industrial facilities. According to the World Bank Reports (2019) [6], poor state of facilities maintenance in Sub-Saharan Africa is high and it cuts national economy growth by $2 \%$ points every year and reduces productivity by $40 \%$.

Poor maintenance culture is responsible for a worrisome issue in many developing countries and is a major factor responsible for premature wear and tear of machines and equipment, frequent breakdown of production machines, poor capacity utilization of installed machines, production losses, economic losses and low industrial development. Ejiofor (1987) [7] notes that the state of overall equipment effectiveness of manufacturing firms is a critical issue in Nigeria and that due to poor production facilities management, many manufacturing companies have lost their production efficiency and have witnessed induced inefficiency over the years. Some of the operating companies in the Nigerian cement manufacturing industry have low maintenance culture and do not give adequate attention to production facilities maintenance for overall equipment effectiveness, owing to the fact that the management often looks at maintenance function as a non-value added and cost consuming activity and this has led to loss of their competitive advantage, as well as poor corporate performance.

\section{Research objectives and hypotheses}

\subsection{Research objectives}

The specific objectives of this study are to:

(1) Examine the effect of OEE machine availability rate on ROI in the Nigerian cement manufacturing industry.

(2) Determine the effect of OEE machine performance rate on ROI in the Nigerian cement manufacturing industry.

(3) To evaluate the effect of OEE product quality rate on ROI in the Nigerian cement manufacturing industry.

\subsection{Research hypotheses}

The study seeks to validate the following hypotheses:

(1) OEE machine availability rate has significant positive impact on ROI in the Nigerian cement manufacturing industry.

(2) OEE machine performance rate has significant positive impact on ROI in the Nigerian cement manufacturing industry.

(3) OEE product quality rate has significant positive impact on ROI in the Nigerian cement manufacturing industry.

\section{Literature review}

The concept of overall equipment effectiveness is not new in the discourse of zero waste production, total productive maintenance, production systems availability and reliability, optimization of production facilities, product quality management and maintenance measurement metric. In meeting up with the challenges of world-class manufacturing, overall equipment effectiveness has become an important subject in the literature of maintenance management and manufacturing performance. In the contemporary industrial phase, overall equipment effectiveness is gaining weight as evidenced in the numerous research works [8-10].

Overall equipment effectiveness is a measure of plant improvement which focuses on the concept of zero waste [11]. Pradhan \& Bhol (2006) [12] posit that overall equipment effectiveness is the total productive maintenance metric for measuring equipment effectiveness or productivity. The optimization of equipment, productivity and continuous improvement of equipment for manufacturing process is what Ding \& Kamaruddin (2015) [10] depict as overall equipment effectiveness. Normariah, Salina, Shuib \& Hasnida (2017) [13] view overall equipment effectiveness as a metric that is a function of equipment availability, quality rate and equipment performance efficiency.

Studies by Muchiri \& Pintelon, (2008) [14], Marcello, Marco \& Francesco (2009) [15], Jose, Steve, Kelvin \& Horacio (2010) [16], Muchiri, Pintelon, Gelder \& Martin (2010) [17], 
Vijayakumar \& Gajendran (2014) [18]. Ding \& Kamaruddin (2015) [10] admit that overall equipment effectiveness (OEE) is expressed as a function of availability, performance and quality i.e $\mathrm{OEE}=\mathrm{f}(\mathrm{A} \times \mathrm{P} \times \mathrm{Q})$. They further express that other terms which can be used to express overall equipment effectiveness (OEE) are utilization, efficiency and yield. Utilization $(\mathrm{U})$ is the usage rate of the equipment, which is the rate of actual running of the equipment versus availability; efficiency (E) is the output rate of the equipment, that is the ratio of actual sped versus the rated speed of the equipment while the yield $(\mathrm{Y})$ is the quality rate of the equipment, the ratio of good units output versus total units input of the equipment.

Overall equipment effectiveness measures the effectiveness and efficiency of a machine centre or process line in manufacturing operations on the basis of availability, performance and quality. The value of overall equipment effectiveness (OEE) of 1 or $100 \%$ represents the absolute best performance of a machine. Overall equipment effectiveness as a concept has key objective of eliminating or minimizing losses in a production system, caused by machine failures and stoppages. As many manufacturing organizations focus on minimization of losses resulting from downtime, which affect production schedules, the need for overall equipment effectiveness becomes critical in measuring the effectiveness of planned production schedules and determining the overall plant efficiency.

In today's cement manufacturing industry, overall equipment effectiveness serves as one of the key benchmarking tools that focus on improving the performance and efficiency of machinery and manufacturing process. The capital intensive cement plant machinery that comprises of crusher, grinder, mixer, kiln, silo, loader, conveyor, shovel loader and control room machines that do not receive adequate maintenance tends to drift away from optimum operational performance, asset productivity or capacity utilization and financial performance This may also lead to degraded manufacturing process control and production losses and wastes, which may affect the profitability objective function of business. Osama (2010) [19] studied "Total productive maintenance reviewed and overall equipment effectiveness measurement" in Jordan and the result of the study depicts that loss of OEE is due to poor maintenance function and it negatively affect the performance of a manufacturing company. Fore \& Zuze (2010) [20] executed a study in Zimbabwe on "Improvement of overall equipment effectiveness through total productive maintenance". The investigation also finds out that overall equipment ineffectiveness has significant negative relationship with manufacturing performance.

Bangar, Hemlata \& Jagmohan (2013) [21] carried out a research investigation in Indian on "Improving overall equipment effectiveness by implementing total productive maintenance in auto industry" The results of the study shows significant positive relationship between OEE that is above $85 \%$ and manufacturing performance. Kumar, Soni \& Geeta, (2013) [22] conducted a study in Bhopal on "Maintenance performance metrics for manufacturing industry". The finding of the study shows that overall equipment effectiveness at $90 \%$ is a critical success factor influencing survival, profitability and competitive advantage of manufacturing organization.

Disha, Vijaya, Naidu \& Veena (2013) [23] performed a study in Indian on "Evaluation of OEE in a continuous process industry on an insulation line in a cable manufacturing unit". The result of the empirical analysis of the study shows that 52.96\% OEE of the company, which was below OEE bench mark had significant negative relationship on manufacturing performance. Pradeep, Raviraj \& Lewlyn (2014) [24] conducted a study in India, investigating "Overall equipment efficiency and productivity of a newspaper printing machine of a daily news paper company: A case study". Thus the result of the investigation reveals no significant relationship between OEE and manufacturing performance while the work of Lalit, Gupta \& Zanwar (2014) [25] carried out in Nagpur on "Overall Equipment effectiveness improvement: A case of injection moulding machine" indicates that a $1 \%$ increase in OEE has significant positive effect on manufacturing performance.

\section{Conceptual framework model}

The model below is the conceptual framework of the study. In the model, the study variables are operationalised, indicating the relationship between indicators of overall equipment effectiveness and return on investment index of financial performance. (See Figure 1)

The above conceptual framework model is an exposition of this present study. In the context of this study, the relationship between financial performance (return on investment - ROI) and overall equipment effectiveness indicators (machine availability rate, machine performance rate and product quality rate) form the domain and main thrust in conducting this investigation.

The indicators of overall equipment effectiveness are the unique strengths and core competencies that allow a manufacturing organization to achieve efficiency in production, quality, cost effectiveness or low cost leadership, on-time-delivery (OTD) and flexible manufacturing system 


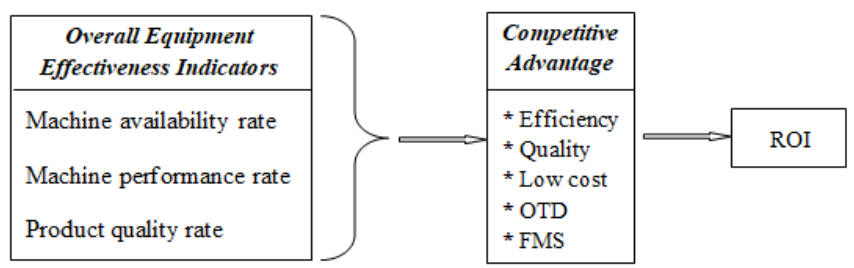

Figure 1 Researchers' conceptual framework model (2020)

(FMS) for optimal performance. The competitive advantage as depicted in the framework model describes the attributes that allow a manufacturing organization to outperform its competitors. It is a superior performance relative to other competitors in the same industry. The competitive advantage arising from the indicators of overall equipment effectiveness enable a manufacturing firm to remain in business in the face of intense competition resulting from globalization of manufacturing activities and markets.

The financial performance of a manufacturing firm is a measure of how well the firm can use its assets to generate revenue or profit. Thus, financial performance is a performance measure or metric that is expressed as overall profits or losses from its business activities over a period of time. Due to a firm's competitive advantage as a result of overall equipment effectiveness, high return on investment that is above the industrial average is earned. Maintenance of production facilities which allows for overall equipment effectiveness remains one of the business functions that serves and supports the primary manufacturing processes through which significant increase in profit can be achieved.

The study therefore sought to explore the extent at which indicators of overall equipment effectiveness as exogenous variables exert impact on ROI financial performance (endogenous variable) in the Nigerian cement manufacturing industry.

\section{Research methodology and model}

\subsection{Methodology}

The study adopted ex-post facto research design in conducting empirical investigation of cause-and-effect relationship of the study's variables. The study used 15-year period (20052019) panel data derived from annual financial reports, maintenance scorecards and production scorecards of cement manufacturing companies quoted in the Nigerian Stock Exchange. The Ordinary Least Squares (OLS) estimator was adopted for the regression analysis of the study.

\subsection{Model specification}

$$
\mathrm{RQI}_{i t}=\mathrm{a}_{0}+\mathrm{a}_{1} \mathrm{MAR}_{i t}+\mathrm{a}_{2} \mathrm{MPR}_{i t}+\mathrm{a}_{3} \mathrm{PQR}_{i t}+\mu_{i t}
$$

Where:

$\mathrm{ROI}=$ Return on investment as a proxy for financial performance and the dependent variable . MAR $=$ Machine availability rate as a proxy for overall equipment effectiveness and independent variable.

MPR = Machine performance rate as a proxy for overall equipment effectiveness and independent variable.

$\mathrm{PQR}=$ Product quality rate as a proxy for overall equipment effectiveness and independent variable.

$\mathrm{a}_{0}$ is the autonomous variable (constant or intercept) while $\mathrm{a}_{1}, \mathrm{a}_{2}$, and $\mathrm{a}_{3}$ are the coefficients of the explanatory (independent) variables of the model; $\mu$ is the error term; ${ }_{i}$ is the individual dimension and $t$ is the time dimension.

\section{Results and interpretation}

The results of Augmented-Dickey-Fuller (ADF) unit root test in table 1 above indicate that at $5 \%$ significant level, the statistical properties of indicators of OEE (MAR, MPR, PQR) have no unit root, which implies that they are stationary or constant over time. (See Table 1) 
Table 1 Augmented-Dickey-Fuller (ADF) unit root test

\begin{tabular}{|c|c|c|c|c|}
\hline & & & t-Statistic & Prob.* \\
\hline $\begin{array}{l}\text { Null Hypothesis: D(MAR) has a unit root } \\
\text { Exogenous: Constant } \\
\text { Lag Length: } 0 \text { (Automatic - based on SIC, maxlag = 3) }\end{array}$ & $\begin{array}{l}\text { Augmented Dickey-Fuller test statistic } \\
\text { Test critical values: }\end{array}$ & $\begin{array}{r}1 \% \text { level } \\
5 \% \text { level } \\
10 \% \text { level }\end{array}$ & $\begin{array}{l}-3.274197 * \\
-4.057910 \\
-3.119910 \\
-2.701103\end{array}$ & 0.0386 \\
\hline $\begin{array}{l}\text { Null Hypothesis: D(MAR) has a unit root } \\
\text { Exogenous: Constant } \\
\text { Lag Length: } 0 \text { (Automatic - based on SIC, maxlag = 3) }\end{array}$ & $\begin{array}{l}\text { Augmented Dickey-Fuller test statistic } \\
\text { Test critical values: }\end{array}$ & $\begin{array}{r}1 \% \text { level } \\
5 \% \text { level } \\
10 \% \text { level }\end{array}$ & $\begin{array}{l}-3.913871^{*} \\
-4.057910 \\
-3.119910 \\
-2.701103\end{array}$ & 0.0112 \\
\hline $\begin{array}{l}\text { Null Hypothesis: D(MAR) has a unit root } \\
\text { Exogenous: Constant } \\
\text { Lag Length: } 0 \text { (Automatic - based on SIC, maxlag = 3) }\end{array}$ & $\begin{array}{l}\text { Augmented Dickey-Fuller test statistic } \\
\text { Test critical values: }\end{array}$ & $\begin{array}{r}1 \% \text { level } \\
5 \% \text { level } \\
10 \% \text { level }\end{array}$ & $\begin{array}{l}-3.824684 * \\
-4.057910 \\
-3.119910 \\
-2.701103\end{array}$ & 0.0149 \\
\hline
\end{tabular}

Notes: * Significant at $5 \%$ level (stationary/has no unit root)

Table 2 is the heteroskedasticity test results of OEE indicators (MAR, MPR \& PQR). The F-statistic value (1.314317) > Critical chi-square value (16.919) and it signifies that the error terms have the same variance (i.e the variance is constant). In this case, the indicators of OEE have no heteroskedasticity, meaning it is homoskedasticity. (See Table 2)

Table 2 Heteroskedasticity test

\begin{tabular}{lrr}
\hline F-statistic & Obs*R-squared & Scaled explained SS \\
\hline $1.314317^{* *}$ & 10.72609 & 3.365906 \\
Prob. F(9.5) $16.919^{* *}$ & Prob. Chi-Square(9) & Prob. Chi-Square(9) \\
0.3662 & 0.2914 & 0.9479 \\
\hline
\end{tabular}

Notes: Null Hypothesis: OEE indicators have no heteroskedasticity; Heteroskedasticity Test: White; ** No significant heteroskedasticity (homoskedasticity)

The regression test results in table 8.3 above depict that in the Nigerian cement manufacturing industry, MAR, MPR \& PQR indicators of OEE have positive coefficient signs of $0.59,0.61 \&$ 0.53 . With these coefficient signs, it means a percentage increase in MAR, MPR \& PQR have direct proportional positive impact on ROI. The Durbin-Watson statistic value of 1.86 signifies positive relationship between the dependent variable (ROI) and the independent variable(s) (OEE - MAR, MPQ \& PQR). Also, the R-squared value of $88 \%$ and the Adjusted R-squared value of $86 \%$ are clear indication that there is a strong evidence of goodness of fit of the regression model. Since the F-statistic and the Prob (F-statistic) are $32.82 \& 0.00$, it means that the estimated model is significant. The p-values of the independent variables indicate statistical significance of the hypothetical test results. Thus, OEE machine availability rate, OEE machine performance rate and OEE product quality rate have significant positive impact on ROI in the Nigerian cement manufacturing industry. (See Table 3)

Table 3 Heteroskedasticity test

\begin{tabular}{|c|c|c|c|c|}
\hline Variable & Coefficient & Std. Error & $\mathrm{t}$-Statistic & Prob. \\
\hline $\mathrm{C}$ & -107.184200 & 13.494080 & -7.943053 & 0.000000 \\
\hline MAR & 0.591555 & 0.512871 & 2.373496 & 0.015900 \\
\hline MPR & 0.610972 & 0.327275 & 2.500183 & 0.016100 \\
\hline PQR & 0.527537 & 0.486470 & 2.618880 & 0.013800 \\
\hline R-squared & 0.880168 & \multicolumn{2}{|c|}{ Mean dependent var } & 19.253130 \\
\hline Adjusted R-squared & 0.868154 & \multicolumn{2}{|c|}{ S.D. dependent var } & 8.038261 \\
\hline S.E. of regression & 2.735801 & \multicolumn{2}{|c|}{ Akaike info criterion } & 5.013556 \\
\hline Sum squared resid & 92.739240 & \multicolumn{2}{|c|}{ Schwarz criterion } & 5.201429 \\
\hline Log likelihood & -31.724210 & \multicolumn{2}{|c|}{ Hannan-Quinn criter. } & 4.811374 \\
\hline F-statistic & 32. 82947 & \multirow{2}{*}{\multicolumn{2}{|c|}{ Durbin-Watson stat }} & 1.864152 \\
\hline Prob (F-statistic) & 0.000000 & & & \\
\hline
\end{tabular}

Notes: Dependent Variable: ROI; Method: Least Squares; Sample: 2005 - 2019; Included observations: 15 


\section{Discussion}

This study estimated the impact of overall equipment effectiveness on ROI in the Nigerian cement manufacturing industry. With the coefficient value $>0$, Prob.-value $<0.05$ and tStatistic value $\geq 2$ in the regression results in table 8.3 above, overall equipment effectiveness has significant positive impact on return on investment in the Nigerian cement manufacturing industry. The three independent variables (MAR, MPR \& PQR) have proved significant in ROI determination in the Nigerian cement manufacturing industry. These independent variables tend to have corresponding impact on ROI, as increase in machine availability rate, machine performance rate and product quality rate as a result of overall equipment effectiveness lead to ROI growth and vice versa.

\section{Conclusion and recommendations}

The study has been able to examine the impact of overall equipment effectiveness on ROI in the Nigerian cement manufacturing industry. Results indicate that the determinants of overall equipment effectiveness (MAR, MPR \& PQR) is significant in determining ROI ratio in the industry. Based on the finding results, the study concludes that the key indicators of overall equipment effectiveness significantly impact on ROI in the industry. The study therefore recommends among others for top management's support and commitment to proactive and continuous improvement production facilities maintenance for improved overall equipment effectiveness and sustainable corporate performance of firms in the industry. Further research should focus on the indicators of production plant uptime, which could impact on ROI in the industry.

\section{Contribution to knowledge and implications}

The contribution to knowledge arising from this study is presented in Figure 2. In the graph, linear correlation exists between the key indicators of OEE and ROI profitability index. As indicated in the graph, the random fluctuation in the OEE and ROI profitability index postulates linear correlation. As the curve which represents indicators of OEE fluctuates, the bar chart that represents ROI proportionally fluctuates. The implication arising from this is that OEE determine the extent of ROI growth and with this, manufacturing companies that use heavy duty equipment can apply this model to make stochastic forecast of trend of OEE and ROI in maximizing their corporate goals.

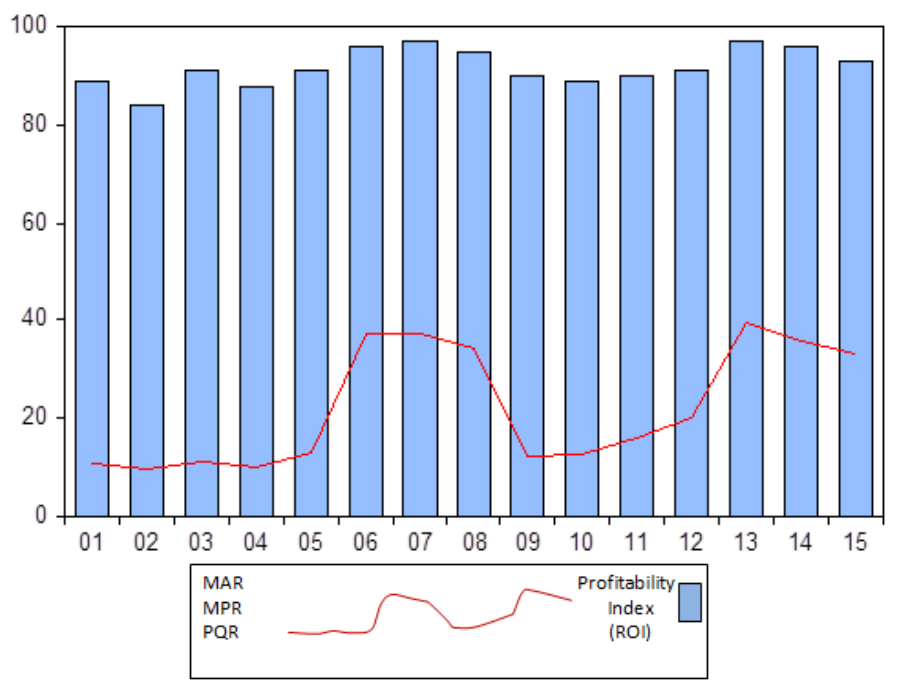

Figure 2 OEE-ROI stochastic graph 


\section{References}

[1] Ebomah EM. Effect of production facilities maintenance o corporate performance of Nigerian cement manufacturing industry. Unpublished PhD Dissertation in the Department of Business Administration, Anambra State University, Nigeria, 2017.

[2] Blischke WR and Murthy DNP. Case studies in reliability and maintenance. New Jersey: John Wiley, 2003. https://doi.org/10.1002/0471393002

[3] Jackson MC. Systems thinking: Creative holism for managers. New York: John Wiley and Sons Inc, 2003.

[4] Liliane P and Parodi-Herz A. Maintenance: An evolutionary perspective. United Kingdom: SpringerVerlag London Ltd, 2008.

[5] Ricardo R and Wade D. Corporate performance management: How to build a better organization through measurement driven strategies alignment. United Kingdom: Butterworth Heinemann, 2001

[6] World Bank. World development report on infrastructure for development: World development indicators. Geneva: World Bank, 2019.

[7] Ejiofor PNO. Management in Nigeria: Theories and issues. Onitsha: African-Feb Publishers Limited, 1987.

[8] Perumal P, Teoh YS and Tay CC. Consideration of demand rate in overall equipment effectiveness (OEE) on equipment with constant process time. Journal of Industrial Engineering and Management, 2013, 6(2): 507-524. https://doi.org/10.3926/jiem.537

[9] Praveen SS, Patel M and Vivek B. A Literature review on overall equipment effectiveness. International Journal of Research in Aeronautical and Mechanical Engineering, 2014, 2(2): 35-42.

[10] Ding H and Kamaruddin A. Is overall equipment effectiveness universally applicable? The case of Saint-Gobain. International Journal of Economics \& Finance, 2015, 7(2): 241-252. https://doi.org/10.5539/ijef.v7n2p241

[11] Hilmola OP. Total productivity measurement and competitiveness: Towards ensuring sustainable business performance in manufacturing organizations: A literature review. International Journal of Process Management and Benchmarking, 2005, 1(1): 45-62. https://doi.org/10.1504/IJPMB.2005.006111

[12] Pradhan MK and Bhol JP. Trends and perspectives in industrial maintenance management. Industrial Maintenance Management, 2006: 27-35.

[13] Normariah CM, Salina B, Shuib S, et al. Synthesizing the machine's availability in overall equipment effectiveness. Journal of Mechanical Engineering, 2017, 4(3): 89-99.

[14] Muchiri P and Pintelon L. Performance measurement using overall equipment effectiveness (OEE): Literature review and practical application discussion. International Journal of Production Research, 2008, 46(13): 3517-3535. https://doi.org/10.1080/00207540601142645

[15] Marcello P, Marco F and Francesco Z. Overall equipment effectiveness of a manufacturing line (OEEML): An integrated approach to assess systems performance. Journal of Manufacturing Technology Management, 2009, 20(1): 8-29. https://doi.org/10.1108/17410380910925389

[16] Jose AG, Steve E, Kelvin DB, et al. Overall equipment effectiveness (OEE) and process capability (PC) measures: A relationship analysis. International Journal of Quality and Reliability Management, 2010, 27(1): 48-62. https://doi.org/10.1108/02656711011009308

[17] Muchiri P, Pintelon L, Gelders L, et al. Development of maintenance function performance measurement framework and indicators. International Journal of Production Economics, 2008, 131(1) 295-302. https://doi.org/10.1016/j.ijpe.2010.04.039

[18] Vijayakumar SR and Gajendran S. Improvement of overall equipment effectiveness in injection moulding process industry. IOSR Journal of Mechanical and Civil Engineering, 2014: 47-60.

[19] Osama TRA. Total productive maintenance review and overall equipment effectiveness measurement. Journal of Mechanical and Industrial Engineering, 2010, 4(4): 517-522.

[20] Fore S and Zuze L. Improvement of overall equipment effectiveness through total productive maintenance. World Academy of Science, Engineering and Technology, 2010, 37: 402-410.

[21] Bangar A, Hemlata S and Jagmohan B. Improving overall equipment effectiveness by implementing total productive maintenance in auto industry. International Journal of Emerging Technology and Advanced Engineering, 2013, 3(6): 590-594.

[22] Kumar, J., Soni, V. K. \& Geeta, A. (2013). Maintenance performance metrics for manufacturing industry. International Journal of Research in Engineering and Technology, 2(2), 136-142. https://doi.org/10.15623/ijret.2013.0202009

[23] Disha MN, Vijaya KMN, Naidu GS, et al. Evaluation of OEE in a continuous process industry on an insulation line in a cable manufacturing unit. International Journal of Innovative Research in Science, Engineering and Technology, 2013, 2(1): 1629-1634. 
[24] Pradeep K, Raviraj S and Lewlyn LRR. Overall equipment efficiency and productivity of a news paper printing machine of a daily news paper company: A case study. International Journal of Engineering Practical Research, 2014, 3(1): 20-27. https://doi.org/10.14355/ijepr.2014.0301.04

[25] Lalit DG, Gupta MM and Zanwar DR. Overall equipment effectiveness improvement: A case of injection moulding machine. International Journal of Engineering and Sciences (IJES), 2014, 3(8): $1-10$. 